\title{
First record of Bathygobius hongkongensis (Perciformes: Gobiidae) from Jeju Island, Korea
}

\author{
Hyuck Joon Kwun (D)
}

\begin{abstract}
Six specimens of Bathygobius hongkongensis were collected for the first time from the eastern coast of Jeju Island, Korea, in September-November 2017. This species is characterized by a pectoral fin with free rays and the division of the first dorsalmost pectoral free ray into three branches; a lower jaw with a mental frenum; and an anterior nostril with a tiny flap. Bathygobius hongkongensis is similar to B. fuscus but differs in having more dorsalmost free pectoral fin rays. The new Korean name proposed for B. hongkongensis is "Nam-bang-mu-nui-mang-duk."
\end{abstract}

Keywords: Gobiidae, First record, Bathygobius hongkongensis, Jeju Island, Tidal pool

\section{Background}

Jeju Island, the largest and most southern island of Korea, is the habitat for many subtropical and temperate marine fishes (Kim 2009), and various fish species have recently been reported for the first time in its coastal waters, including in tidal pools (Jang et al. 2018; Kim et al. 2018; Kwun et al. 2016). Jeju Island is affected by the Kuroshio Warm Current (Kim et al. 2009), so it can be regarded as the boundary area in which tropical and subtropical fishes first appear in Korean waters.

The family Gobiidae, one of the largest fish taxa, contains 189 genera and 1359 species worldwide, and most species are distributed in tropical and subtropical regions (Nelson et al. 2016). Marine Gobiidae species inhabit benthic environments on mud, sand, and rocky substrates, from the coast to the continental slope, including estuaries (Hastings et al. 2014). The genus Bathygobius Bleeker 1878 is a representative group of this family, and 28 species are recognized worldwide (Froese and Pauly 2019). This genus is characterized by a chin with a mental frenum and free tips of the upper pectoral fin rays (Akihito et al. 2013; Larson and Murdy 2001). In Korea, only one species of the genus, Bathygobius fuscus (Rüppell 1830) has been reported until now (Kim et al. 2005).

In the present study, six specimens of the genus Bathygobius were collected from a tidal pool on Jeju Island, and were identified as Bathygobius hongkongensis Lam 1986 based on morphology. This species is previously unrecorded in Korean waters, so it is reported for the first time and its morphology described.

\section{Methods}

Six specimens of $B$. hongkongensis were collected with a hand net from a tidal pool on the eastern coast of Jeju Island between September and November 2017 (Fig. 1), and were fixed as whole bodies in 99\% ethanol. All counts and measurements were made according to Hubbs et al. (2004), and measurements were made to the nearest $0.1 \mathrm{~mm}$ with a digital Vernier caliper. The fin rays were counted under a stereomicroscope (SZX16, Olympus, Japan), and the vertebrae were counted from a radiograph (VIX-100, Softex, Japan). The specimens have been deposited at the National Marine Biodiversity Institute of Korea, Marine Fish Diversity (MFD).

(c) The Author(s). 2020 Open Access This article is licensed under a Creative Commons Attribution 4.0 International License, which permits use, sharing, adaptation, distribution and reproduction in any medium or format, as long as you give appropriate credit to the original author(s) and the source, provide a link to the Creative Commons licence, and indicate if changes were made. The images or other third party material in this article are included in the article's Creative Commons licence, unless indicated otherwise in a credit line to the material. If material is not included in the article's Creative Commons licence and your intended use is not permitted by statutory regulation or exceeds the permitted use, you will need to obtain permission directly from the copyright holder. To view a copy of this licence, visit http://creativecommons.org/licenses/by/4.0/. 


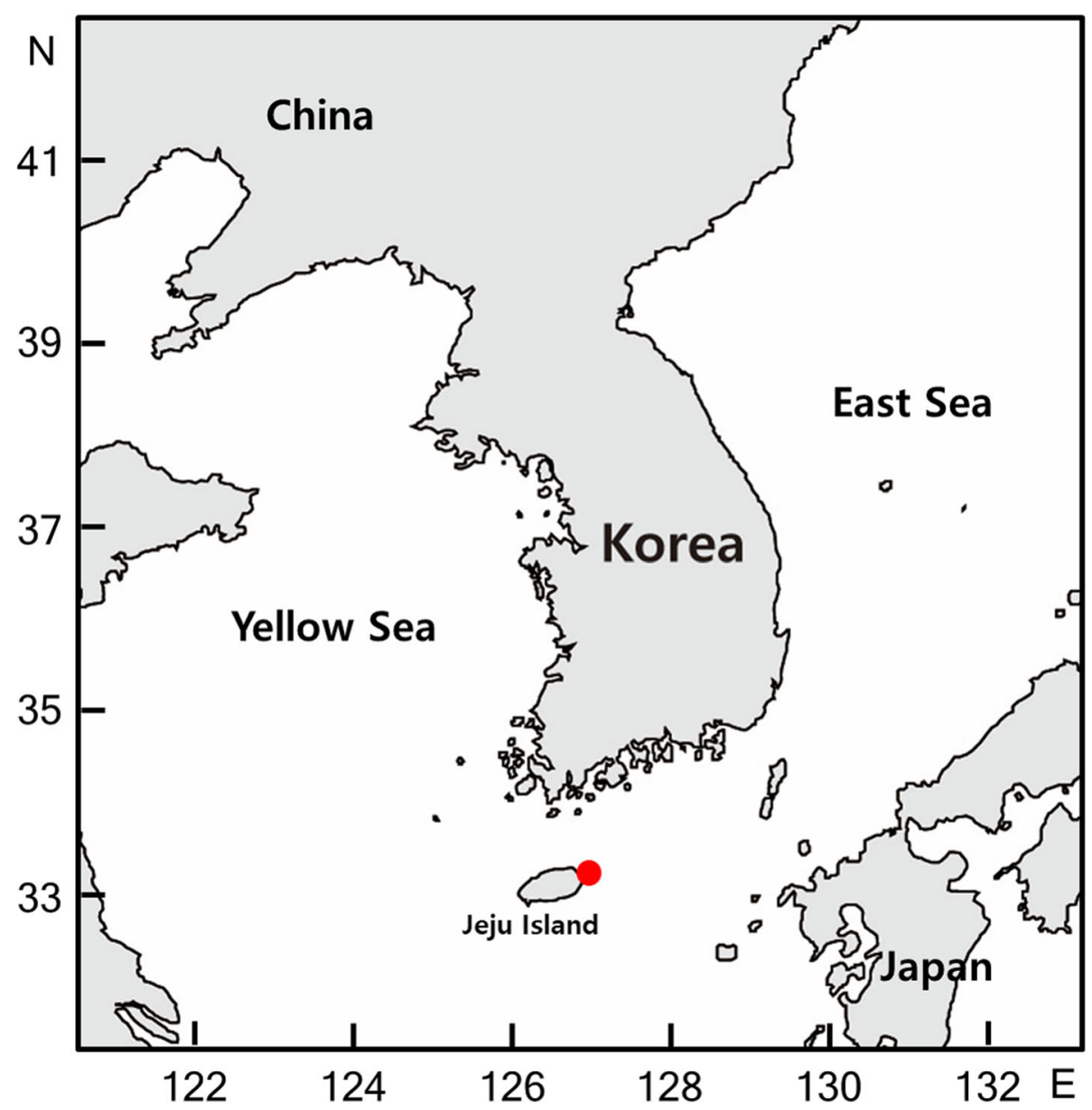

Fig. 1 Map showing the location of Jeju Island and sampling sites

\section{Results}

Bathygobius hongkongensis Lam 1986

(New Korean name: Nam-bang-mu-nui-mang-duk) (Fig. 2)

Bathygobius hongkongensis Lam 1986: 76. TL: Chung

Hum Kok, Hong Kong; Motomura et al. 2010: 206; Shen and Wu 2011: 674; Prokofiev 2016: 644.

\section{Examined material}

MFD-1192-1193, 2 specimens, 24.2-31.5 mm standard length (SL), Seongsan-ri $\left(33^{\circ} 27^{\prime} 36.03^{\prime \prime} \mathrm{N}, 126^{\circ} 56^{\prime}\right.$ 06.66" E), Seongsan-eup, Seogwipo, Jeju Island, hand net, 7 Sep. 2017; MFD-1231-1232, 2 specimens, 28.3$34.8 \mathrm{~mm}$ SL, Seongsan-ri $\left(33^{\circ} 27^{\prime} 36.03^{\prime \prime} \mathrm{N}, 126^{\circ} 56^{\prime}\right.$ 06.66" E), Seongsan-eup, Seogwipo, Jeju Island, hand net, 12 Oct. 2017; MFD-1234-1235, 2 specimens, 34.1$34.8 \mathrm{~mm}$ SL, Seongsan-ri $\left(33^{\circ} 27^{\prime} 36.03^{\prime \prime} \mathrm{N}, 126^{\circ} 56^{\prime}\right.$ 06.66" E), Seongsan-eup, Seogwipo, Jeju Island, hand net, 14 Nov. 2017.

\section{Description}

The counts are listed in Table 1. Proportions as \% SL: head length 28.9-31.9; body depth 19.7-22.7; snout length 7.0-8.7; postorbital length 14.4-16.9; caudal peduncle depth 11.7-14.5; predorsal length 34.0-37.8; prepectoral length 29.8-33.3; preanal length 58.0-65.3. Proportions as \% head length (HL): interorbital width 7.7-11.9; eye diameter 22.0-26.2; upper jaw length 17.1-25.2; pectoral fin length 64.9-97.0.

Body moderate and tapering posteriorly. Head slightly blunt and depressed. Anterior nostril with small flap.

Table 1 Comparison of meristic characters of Bathygobius hongkongensis

\begin{tabular}{|c|c|c|c|}
\hline & \multicolumn{3}{|c|}{ Bathygobius hongkongensis } \\
\hline & Present study & Lam (1986) & Akihito et al. (2013) \\
\hline Number of specimens & 6 & 18 & - \\
\hline Standard length (mm) & $24.2-34.8$ & $25.6-45.9$ & - \\
\hline \multicolumn{4}{|l|}{ Counts } \\
\hline Dorsal fin & $V \mid-I, 9$ & $V \mid-I, 9$ & VIII, 9-10 \\
\hline Anal fin & 1,8 & 1,8 & l, 7-8 \\
\hline Pectoral fin & $20-21$ & $19-21$ & - \\
\hline Vertebrae & 27 & 26 & - \\
\hline
\end{tabular}




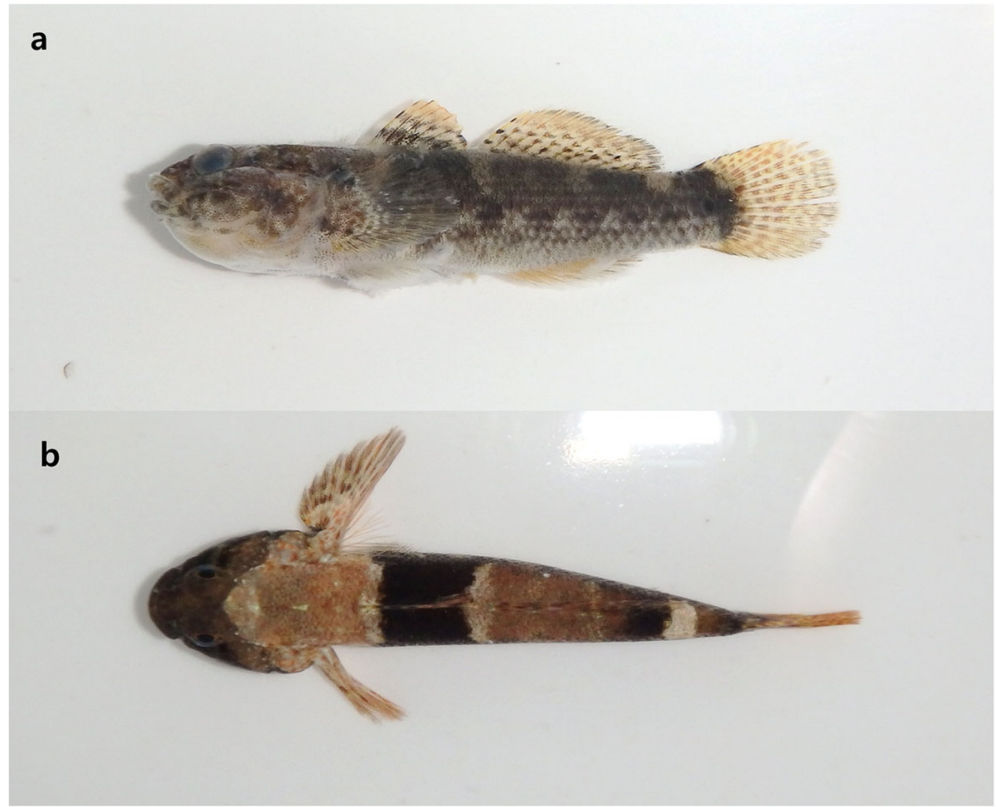

Fig. 2 Bathygobius hongkongensis. a Lateral view, MFD-1192, 31.5 mm SL. b Dorsal view, MFD-1234, 34.8 mm SL

Snout short, mouth terminal, and both lips thick. Upper and lower jaws with irregular rows of small conical teeth. Posterior tip of maxilla not reaching anterior margin of eye. Posterior margin of mental frenum slightly straight. Two dorsal fins separated. Origin of anal fin located behind origin of second dorsal fin. Upper rays of pectoral fin free from membrane (Fig. 3) and first dorsalmost free ray divided into three branches. Pelvic disk circular. Caudal fin rounded. Body covered in scales from predorsal and preanal regions to caudal base. Head without scales. Welldeveloped sensory canal system on head.

\section{Coloration}

When fresh, head and body speckled darkish brown dorsally and whitish ventrally. Wide blackish brown blotch, like a band, on the body below the first dorsal fin (Fig. 2b). Small dark spot on upper pectoral fin base. All fins semitransparent and pale brown, and dorsal, caudal, and pectoral fins with several small brown spots.

\section{Distribution}

Bathygobius hongkongensis is distributed in parts of the western Pacific region, including around Hong Kong, Vietnam, Taiwan, and Japan (Akihito et al. 2013; Froese and Pauly 2019; Lam 1986; Prokofiev 2016; Shen and $\mathrm{Wu}$ 2011). The present specimens were found in an intertidal rockpool on the eastern coast of Jeju Island.

\section{Discussion and conclusion}

The present specimens can be assigned to the genus Bathygobius based on the following characters: the presence of a small flap at the tip anterior nostril, the tip of upper pectoral fin is free from the fin membrane and the lower jaw has a mental frenum (Akihito et al. 2013; Larson and Murdy 2001). The specimens were identified as $B$. hongkongensis because they correspond to the original description of that species (Lam 1986): first free upper pectoral fin separated into three branches, the posterior margin of the mental frenum is straight, and the cheek and operculum have no scales. When B. hongkongensis is compared with the closely related species $B$. fuscus, the former differs from the latter in having more dorsalmost free pectoral fin rays (9-22 in B. hongkongensis vs. 5-7 in B. fuscus), total length (TL) $>25$ $\mathrm{mm}$, and a small flap on the anterior nostril (present vs. absent, respectively) (Lam 1986; Akihito et al. 2013).

Bathygobius hongkongensis inhabits rocky shores in tropical and subtropical regions such as Hong Kong,

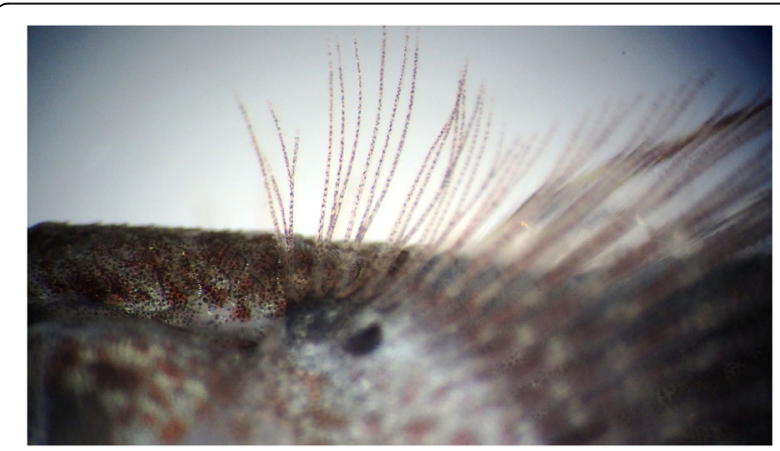

Fig. 3 Free rays on the dorsalmost pectoral fins, MFD-1231, $34.8 \mathrm{~mm} \mathrm{SL}$ 
Thailand, Taiwan, and Japan (Froese and Pauly 2019), and adult specimens have now been found in the southern region of Korea. This represents an extension of the $B$. hongkongensis range northward into the western $\mathrm{Pa}-$ cific. The new Korean name, "Nam-bang-mu-nui-mangduk" is proposed for B. hongkongensis.

\section{Acknowledgements}

Not applicable

\section{Author's contributions}

Author collects a specimen and writes the manuscript. The author(s) read and approved the final manuscript.

\section{Funding}

This work was supported by the National Marine Biodiversity Institute of Korea Research Program (2020 M00100).

\section{Availability of data and materials \\ Not applicable}

Ethics approval and consent to participate

Not applicable

\section{Consent for publication}

Not applicable

\section{Competing interests}

The author reports no competing interests.

Received: 19 December 2019 Accepted: 1 July 2020

Published online: 29 July 2020

\section{References}

Akihito SK. Ikeda Y, Aizawa M. Gobiidae. In: NakaboT, editor. Fishes of Japan with pictorial keys. 3rd ed. Tokyo: Tokai University Press; 2013

Bleeker P. Quatrième mémoire sur la faune ichthyologique de la NouvelleGuinée. Arch Néerl Sci Exact Nat. 1878;13:35-66.

Froese R, Pauly D. FishBase. 2019. http://fishbase.org.

Hastings PA, Walker HJ Jr, Galland GR. Fishes: a guide to their diversity. Oakland: University of California Press; 2014.

Hubbs CL, Lagler KF, Smith GR. Fishes of the Great Lakes region. Revised ed. Ann Arbor: The University of Michigan Press; 2004.

Jang SH, Kim JK, Heo Y, Yu HJ, Park JH. New record of a bothid, Kamoharaia megastoma (Pleuronectiformes), in southern Jejudo Island. Korea. Korean J Ichthyol. 2018:30:175-80.

Kim BJ, Kim IS, Nakaya K, Yabe M, Choi Y, Imamura H. Checklist of the fishes from Jeju Island. Korea. Bull Fish Sci Hokkaido Univ. 2009:59:7-36.

Kim JK. Diversity and conservation of Korean marine fishes. Korean J Ichthyol. 2009;:21:52-62.

Kim MJ, Kim JS, Song CB. First record of the doublespotted queenfish, Scomberoides lysan (Perciformes: Carangidae) from Korea. Korean J Ichthyol. 2018:30:242-6.

Kwun HJ, Park J, Kim HS, Bae H. First record of the banded sergeant, Abudefduf septemfasciatus (Perciformes: Pomacentridae) from Jeju Island. Korea. Korean J Ichthyol. 2016;28:47-51.

Lam C. A new species of Bathygobius (Pisces: Gobiidae) from Hong Kong. Asian Mar Biol. 1986;3:75-87.

Larson HK, Murdy EO. Gobiidae. In: Carpenter KE, Niem VH, editors. FAO species identification guide for fishery purposes. The living marine resources of the Western Central Pacific. Vol 6. Bony fishes part 4 (Labridae to Latimeriidae), estuarine crocodiles, sea turtles, sea snakes and marine mammals. Rome: Food and Agriculture Organization of the United Nations; 2001.

Motomura H, Kuiiwa K, Katayama E, Senou H, Ogihara G, Meguro M, Matsunuma M, Takata Y, Yoshida T, Yamashita M, Kimura S, Endo H, Murase A, Iwatsuki Y, Sakurai Y, Harazaki S, Hidaka K, Izumi H, Matsuura K. Annotated checklist of marine and estuarine fishes of Yaku-shima Island, Kagoshima, southern Japan. In: Motomura H, Matsuura K, editors. Fishes of Yaku-shima Island. Tokyo: National Museum of Nature and Science; 2010.
Nelson JS, Grande TC, Wilson MVH. Fishes of the world. 5th ed. Hoboken: John Wiley and Sons; 2016

Prokofiev AM. Gobies (Gobioidei) of soft bottoms from Nha Trang and Van Phong bays (South China Sea, Vietnam). J Ichthyol. 2016;56:799-817.

Rüppell E. Atlas zu der Reise im nördlichen Afrika. Fische des Rothen Meers. Frankfurt: Heinrich Ludwig Brönner; 1828-1830.

Shen S, Wu G. Fishes of Taiwan. National Museum of Marine Biology and Aquarium: Pingtung; 2011.

\section{Publisher's Note}

Springer Nature remains neutral with regard to jurisdictional claims in published maps and institutional affiliations.

\section{Ready to submit your research? Choose BMC and benefit from:}

- fast, convenient online submission

- thorough peer review by experienced researchers in your field

- rapid publication on acceptance

- support for research data, including large and complex data types

- gold Open Access which fosters wider collaboration and increased citations

- maximum visibility for your research: over $100 \mathrm{M}$ website views per year

At $\mathrm{BMC}$, research is always in progress.

Learn more biomedcentral.com/submissions 